\title{
The Internal Political Situation in the Ottoman Empire during the First Balkan War on Materials of Tatar Journalists
}

\author{
Kamil G. Akhsanov ${ }^{1}$, Makhfuza A. Rustamova ${ }^{1} \&$ Zukhra A. Motygullina $^{1}$ \\ ${ }^{1}$ Kazan (Volga Region) Federal University, Kazan, Russia \\ Correspondence: Kamil G. Akhsanov, Kazan (Volga Region) Federal University, 420008, Kazan, Kremlyovskaya \\ Street 18, Russia. E-mail: kgaxanov@list.ru
}

Received: June 15, 2015 Accepted: June 24, 2015 Online Published: June 30, 2015

doi:10.5539/jsd.v8n7p16 URL: http://dx.doi.org/10.5539/jsd.v8n7p16

\begin{abstract}
The relevance of the investigated problem is caused by the need of the coverage of little-known episodes in the Russian-Turkish relations, which is the period of the Balkan wars. The purpose of the article is to analyze the materials of the Tatar journalists, who worked in Istanbul in the first months of the Balkan War (November-December 1912) and studied he political situation in the Ottoman Empire. We use historical and situational method, as a leading approach to the investigation of this problem which involves the study of historical facts in the context of the era being studied in conjunction with the "neighboring" events and facts. Having studied the materials of the Tatar journalists that were in Istanbul during the Balkan War, we can conclude that they had close ties with their local counterparts, as well as many Ottoman politicians, and have seen, and possibly were the members of the political struggle in the capital of the Ottoman Empire. The materials may be useful for a deeper and more accurate coverage of history, both Turkey and the Muslims of Russia.
\end{abstract}

Keywords: Balkan War, Ottoman Empire, Turkey, F. Karimi, "Vakyt." "Yoldyz" "Ittihad ve Terakki" (Young Turks), G. Kamal

\section{Introduction}

The relevance of the investigated problem is caused by the need of the coverage of the little-known episodes in the Russian-Turkish relations and the role of Muslims living in the Russian Empire in the overall picture of the Russian-Ottoman relations in the early XX century. The relationships of Volga-Ural Tatars and Anatolian Turks living in Russia have a long history, from the time of the Golden Horde - the Kazan Khanate and the Ottoman Empire. After the fall of Kazan and other Tatar khanate the Ottoman Turkey was seen as a significant part of the Tatars stronghold of Islam as a possible liberator, an ally in the fight against the Russian autocracy. However, with the course of time many members of the educated part of the Volga and Ural Tatars became more sober in the assessment of the possibility of a weakening of the Ottoman Empire, but nevertheless cultural ties between the Volga-Ural region of the Ottoman Empire continued to persist. A new surge of interest in Russian Turkish Muslims is associated with the Tanzimat period of the reforms undertaken by the Ottoman authorities in the middle of the XIX century in order to overcome the backwardness of the Ottoman Empire from the advanced European countries. The events associated with the Young Turk Revolution and the reign of the Young Turks, i.e. the last decade of the Ottoman Empire (1908-1918) were of particular interest with Russian Muslims.

It can be said that the beginning of the Balkan wars exploded the Tatar community. Catastrophic defeat of Turkish troops in the first weeks of the war and the loss of almost all European areas, except for a few besieged cities seemed like a complete collapse of the once mighty Ottoman Empire. Not limiting reprints and references some of the most readable publication send its correspondents to the area of operations. But arriving in Turkey journalists began to describe not only military action. They found themselves in an acute internal political struggle, which was in the Ottoman Empire at the time.

It should be noted that the beginning of the twentieth century the history of the Tatar people was marked by an unprecedented rise in almost all areas - strengthening the position of the national capital, the movement for reforms in education, the flourishing of national culture, the rise of social movement. "The emergence of the periodical press, theater, success in publishing, various kinds of national art in the field of public education, and so on brought the Tatar people on the high road of universal, but at the same time, the original development" (Amirhanov, 2006). The establishment of Tatar periodicals played a key role in the development of the Tatar 
nation. "The emergence of national periodicals was an unprecedented achievement for the acquisition of the Tatar people, awakened to active social life thanks primarily to the revolution of 1905-1907. No exaggeration to say that newspapers and magazines in their native language opened a new era in the political life of the nation, which was represented by its prominent representatives who showed unprecedented commitment to all new and progressive" (Amirhanov, 2002). In the spiritual life of the Tatar people the appearance of the national press has become a new long-awaited, a phenomenon of the periodical press in their native language, for which the Tatars had been fighting for decades. It should be noted that since its inception Tatar edition covers a wide range of ideological views from the conservative to the extreme left-radical. "The functioning of such an abundance of periodicals in the Tatar language ... indicated a high level of the Tatar journalism maturity of the XX century" (History of the Tatars from the ancient times, 2013).

The internal problems like the struggle for equal rights in matters of public education and the development of national culture became the key themes of publications of Tatar newspapers and magazines, the activities of the deputies of the Muslim fraction in the State Duma were brightly lit. But the Tatar publication is not confined to domestic issues and materials devoted to international politics, they occupied a worthy place among the publications of newspapers and magazines. Naturally, that shows a great interest in the situation in Muslim countries. The Turkish-Ottoman theme won a central place in the pages of the Tatar periodicals. Tatar newspapers and magazines were keenly interested in events that took place in this country. At that it should be noted that some Tatar journalists and editors were in some way connected with Turkey, studying there or having family ties. Momentous events that took place in the Ottoman Empire, found a lively response from the Tatar audience publishing in the Tatar the Young Turk revolution of 1908-1909 and were met with enthusiasm. With sympathy to Turkey wrote Tatar publications during the period 1911-1912 Tripolitanian war. When Italy began a military campaign to seize the last Ottoman possessions in Africa - Tripolitania and Cyrenaica (now Libya). But the greatest impact in the Tatar press trigger events related to the Balkan Wars of 1912-1913. Here, in contrast to Tripolitanian campaign the central regions of the Ottoman were endangered.

The origins of the Balkan conflict go back to the Middle Ages, when the Ottoman Turks crossed the Black Sea straits and began conquests in Europe. In the following centuries, the Ottoman Empire gradually lost its Balkan areas. But even Russian Empire could not totally force the Turks go back to Asia. And by the end of 1912 the Balkan states, united in the "Balkan Union" agreed that a good time had come to defeat Ottoman Turkey. Bulgaria and Serbia, who ruled the Balkan Union, aspired to conquer the most part of Macedonia; in addition, the Bulgarian ruling circles expected to get access to the Aegean Sea for Bulgaria by connecting Thessaloniki and Western Thrace, and the Serbian elite, sought to acquire access to the Adriatic Sea by dividing Albania and Greece. By the time the Ottoman Empire was weakened by uprisings in Macedonia and Albania and the Italian-Turkish Tripolitanian War of 1911-1912, the countries of the Balkan union decided to use the latter. The reason for the declaration of war was the refusal of Turkey to reform its European areas, aimed at providing the autonomy of Macedonia and Thrace, and cancel the mobilization of the Turkish army. On October 9, 1912 Montenegro started military actions against Turkey. On October 18 Bulgaria, Serbia and Greece entered the war. The forces of the Balkan allies were more than half a million of soldiers, of whom more than one third were Bulgarians. At the opening of hostilities Turkey put forward about 400 thousand people. In the first days superiority of the allied forces over the forces of the Ottoman Empire manifested itself. At this time Turkish armed forces were in the process of reorganization and rearmament, and political instability in the Ottoman Empire was also telling. The most severe blow was delivered by the Bulgarian army in Thrace that bound most of the Turkish forces, covering the path to Stambul. Having suffered a number of serious defeats on the side the Bulgarian, Serbian and Greek troops Ottoman army almost lost control of the European areas of the empire (Zadokhin, NIZOVSKIY, 2000). Thus, within a few weeks, the main forces of the Turkish army in the Balkan peninsula were destroyed, except for the three besieged fortresses. The Bulgarian army came up to Istanbul (Vasilyeva \& Gavrilov, 2000).

Only at great cost on November, 17-19 2012 the Turks managed to repulse the attacks on the Bulgarian Chataldzhi positions that were located a few dozen kilometers from the capital of the Ottoman Empire. Imminent threat of Istanbul has been removed, which on December, 31912 promoted between the Allies and Turkey. The conference of ambassadors in London was to decide the fate of peace or war. Thus the initial and most important stage of the First Balkan War ended (Zadokhin \& Nizovski, 2000). Russian diplomacy also played its role in the conclusion of a ceasefire, using its influence on Serbia (In the powder cellar of Europe, 2003). St. Petersburg was not interested in the complete defeat of the Ottoman Empire armies by the Balkan allies, and the capture of Constantinople by Bulgarian troops, because such a scenario pulled the rug out from under Russia's claims to "Constantinople" and the straits zone. Of course, then, in the autumn of 1912 Tatar journalists in one of the 
provinces of the Russian empire could not know all aspects of the Balkan conflict, but nevertheless they have made an important contribution to the coverage events both around the Balkan War, and in the description of the political situation in the capital of the Ottoman Empire.

The purpose of this article is to analyze the materials of Tatar journalists who worked in Istanbul in the first months of the Balkan War (November-December 1912), which describes the political situation in the Ottoman Empire.

\section{Materials and Methods}

A historical and situational method, which involves the study of historical facts in the context of the era studied in conjunction with the "neighboring" events and facts, is used as a leading approach to the study of this problem. We have attracted a wide range of historical literature, which allows to fully understand the situation both around the Ottoman Empire, and the political situation in Turkey during the Balkan wars.

Tatar periodicals of 1912-1913 were also involved, which highlighted the situation on the fronts of the First Balkan War, as well as to assess the developments in the political life of the Ottoman state. We have used such newspapers as "Yoldyz" ("Star"), "Vakyt" ("Time"), "Koyash" ("Sun"), as well as the book "Istanbul letters"by Fatih Karimi, written on the materials, which he sent from Istanbul to newspaper "Vakyt".

The Tatar press tracked events in the Balkans before the outbreak of hostilities. So the newspaper "Yoldyz" of September 18 (old style), 1912 placed an article entitled "Clouds are gathering" on the first page, where the words of the Declaration of the Foreign Minister of Austria-Hungary are quoted: "There are dark clouds over the Balkan peninsula in the air with a very high electric voltage". Further, the author writes that the Balkans faced the interests of the Triple Alliance Powers and the Entente. "Austria, a Triple alliance member, wants, having sown discord in the Balkans, to snatch some piece of it" The author further writes: "Thus, peace and war in the Balkans for the current day in the hands of Turkey, Bulgaria and Austria. It is the matter which is in the hands of the great European states. "In the same issue collection of messages with links to the European edition, which deals with the impending war is placed ("Yoldyz", 1912). Thus, the Tatar community had the opportunity to receive information of European media in their native language, and almost without delay. In its issue of 20 September the Orenburg newspaper "Vakyt" published reports on the military preparations of the Balkan countries and anticipation of a future war. There the internal contradictions in the Ottoman Empire are reported too as well as the recent developments related to the removal from power of the Young Turks and the arrival of their opponents. The newspaper "Vakyt" also publishes information from European capitals based on wire services ("Vakyt", 1912).

"Although the war is not declared - her dark shadow is looming on all sides," the newspaper "Vakyt" dated September 23, 1912 read, expressing the concern that the Balkan war could turn into a pan-European one, the opinion about the involvement of the great European powers into the conflict was suggested ("Vakyt", 1912). The Tatar newspapers cited Russian publications which are generally sympathetic to the fact that Bulgaria acceded Turkish lands. The opinion is worded that the Turks must displaced from Europe to Asia. Ismail Gasprinsky's article can be identified of all the publications of the prewar days that was reprinted by the newspaper "Yoldyz" in its issue dated 23.09.1912 referring to the newspaper "Tardzhuman" [8, № 884]. Here, a well-known educator struck with indignation on public opinion in Bulgaria and other countries that supports terrorist activities of Bulgarian nationalists in the Ottoman Empire.

Already in December 1912 when defeat of the Ottoman Empire in the first stage of the war became apparent the newspaper "Koyash" wrote: "If the Europeans are paying attention to this war in terms of political balance, numerous multi-million Muslims round the world are forced to look at it from a very different standpoint. In this war, the fate of the only preserved to this day an independent Muslim state is the Ottoman Empire. The significance of the results of this war are even more important for Turkic peoples: their ability to live in the twentieth century is tested. When viewed from this perspective, we, Tatars, of course can not remain indifferent: the defeat of the Turks breaks our hearts, we empathize with their distress and shame" ("Koyash", 1912).

The assistance was also rendered in the form of, as it is now said, collected donations, humanitarian aid from the Hilal Ahmar (Turkish analogue of the Red Cross) and so on. The Muslims of the Volga and Ural regions not only closely followed the developments in the Balkan war fronts, collected donations and took care for the wounded. For example, the famous Tatar politician, the writer Yusuf Akchura went to the front with the rank of centurion (yuzbashi), as the editor of "Vakyt", as F. Karimi reported in his book. The younger brother of F. Karimi - Garif participated in the battles, and was even wounded. All in all more than a hundred volunteers from the Russian Muslims took part in military operations (Kərimi, 1913).b 
Apart from reprints and links some of the most readable publication send its correspondents to the area of military operations. But journalists arriving in Turkey began to describe not only military action. They appeared in an acute internal political struggle, which took place in the Ottoman Empire of that time.

\section{Results}

The selected sources and the works of the Russian, Turkish and European researchers attracted allowed us to create an objective picture of political life of the Ottoman Empire in an initial stage of the First Balkan war.

In the autumn of 1912 the Ottoman Turkey endured one of the most dramatic episodes of the history. Heavy defeats of the first days of the Balkan war were aggravated with the extremely intense internal political situation in the country. Taking advantage of the defeat of the Ottoman Empire in the war with Italy, political opponents of the Young Turks (the Party Ittikhad ve tarakki or as they were called - "ittikhadists") made a revolution in July, 1912. It was headed by the Party Hyurriyet Ve Ittilyaf ("Freedom and consent") created in November, 1911, the latter included many opposition parties and groups. The new party was supported by representatives of the ethnic minorities whom they promised to put into practice the principle of autonomy of national areas at preservation of political integrity of the country. "Hyurriyet ve ittilijaf" represented a rather difficult phenomenon and included the representatives of the most different political views: nationalists, liberals, Westerners, sekulyarists etc., besides there were both Muslim Turks, and the representatives not of the Muslim people of the Ottoman Empire among the members of the party (Genel Türk tarihi, 2002.). The cabinet retired, and the new government was headed by the protege of ittilyafist of Kyamil-pasha. The head of the government got the nickname "ingliz (the Englishman), as he had been in close relations with Great Britain for more than twenty years (Finkel, 2007).

Ittilyafists used a military situation to bring down repressions on the political opponents. Many active figures of ittikhadists were arrested (Petrosyan, 2003). The head of the government Kyamil Pasha acted about the offer to call the constitutional meeting. But other members of the cabinet didn't support this approach. Young Turks decided not to interfere with these disputes (Feroz, 2010). So it was the Tatar journalists who tried to understand not a simple political situation in Istanbul.

Being in Istanbul F. Karimi noted two important subjects: the first of them dealt with the beginning of peace negotiations; the second was dedicated to the arrests and detention of party members of "Ittikhad ve terakki" (Unity and progress). F. Karimi reported that a lot of outstanding statesmen were arrested, there being ministers, assistants to ministers, deputies, party functionaries among them. Some representatives of the former country leaders managed to run abroad. On inquiries of the journalists what the Young Turks were guilty of, the answer coinciding with the official point of view of that time followed: "Efendim, can't you see, what fell down on our heads? It was ittikhadists who committed all this crime, small group of people having seized power in the hands, turned the country upside down. On the one hand they incited against themselves all Christians living in our country, on the other hand they cooled love of Europe to us ... They are the reason of our present state". Thinking over the reasons of so rigid attitude of the new authorities to the Young Turks F. Karimi came to conclusion that after making peace the present authorities would be responsible for everything they had done (defeat and loss of huge territories). And on a protest wave the Young Turks who will surely try to return power would be sought after again, which happened months later.

According to F. Karimi's records major internal political confrontation turned out to be the main problem of Turkey: "The majority can recognize that the main reason of today's situation in Turkey was caused by interparty conflicts and it was the civil strifes that were responsible for the defeat of the Turkish army, not Bulgarians. The most educated sections of the population understand it. However, they are so keen on interparty disagreements that, for example: if it is known clearly that "Ittikhad ve terakki", having come to the power, will throw out all enemy troops out of the country, the party resisting categorically to it won't be happy and will prefer Turkey to be captured by the Balkan Slavs to escape prosecutions on the side of ittikhadists, " (Karimi, 1913). Of course, there is an extreme in these reasonings following from the personal sympathies of the author to the Young Turks whom he designates to be "the most capable, talented, and self-sacrificing people, true defenders of the homeland" (Karimi, 1913). According to F. Karimi the aspiration of Turks to shift all blame on ittikhadists proceeded from absence of objective information and trust to words of "sweet-voiced" Greeks and Armenians. "Ittikhadists sought to establish the Turkish power in Turkey. They made hasty errors, but their purposes were right. However ittilyafists with Greeks and Arnauts (Albanians) showed "skill": they became the main reason of reduction or even destruction of the Ottoman power in Europe. Poor frank Turks now praise Arnausts and abuse ittikhadists" (Karimi, 1913).

One of the important aspects of a political situation at the end of 1912, was the question of the Ottoman Empire government form. The restoration of the constitution of 1876 and appointment of the government by most of 
deputies of the Majlis (parliament) became the main results of the Young Turks revolution of 1908-1909. The very need of electoral body is questioned, though informally at the level of rumors. "Among the people the following news extended: as there was no any advantage from the deputies of the Majlis for the period of 4 years and according to the public opinion, the constitutional board isn't perfect, the government liquidates the Chamber of Deputies (the Majlis) and only Shurai devlet (State Council) will be left. Today the government disproves this information through newspapers. The government declares that such intentions didn't exist and it was a completely invented message. However, many consider that this message doesn't look completely groundless. Most likely that not obvious liquidation of deputy corps, but only the change of its value was meant. They wanted to take some steps backwards and if there is no "Ittikhad ve terakki in political arena", someone will hardly oppose such step later" (Karimi, 1913).

Being the journalist himself F. Karimi gives a lot of place to a question of freedom of press, or it is more correct to tell about the absence of it. "I cannot help but mention that the Turkish newspapers that told the truth were closed. There are only the newspapers which flatter current officials, write only to calm down people. They don't say that it is necessary to write the truth, even if it is bitter and unloved with the people. They don't try to form public opinion, being likely to think that they are just follow the mood of the crowd because it is more convenient and safe ... In fact, in the conditions of state of emergency, there is also no opportunity for newspapers to write and tell thoroughly and have discussion based on their information. Therefore it isn't surprising that newspapers can't tear themselves away from the mood of the crowd and can't express the thoughts and criticism of affairs of the government" (Karimi, 1913). The aforesaid concerns only the press which was loyal to the authorities, oppositional editions were neutralized beforehand. According to F. Karimi the Turkish newspapers were especially evident defective phenomenon: "Nothing is written truthfully and with true sense. In comparison with them Ittikhadists' newspapers wrote more truthfully. But today's newspapers write only for the purpose to calm down the crowd, to confuse thoughts, to deceive it. Such phenomenon is already a crime. The enemy approached a capital gate, surrounded it from all directions, forced to ask about the world. Meanwhile the Turkish newspapers discuss constant victories of Turks..." (Karimi, 1913).

F. Karimi comes back to the subject of arrests of the Young Turks almost in each record of November and December, 1912: "Here all of them are brought together and locked in prison. Here only these days near Istanbul in the manor of the famous Egyptian Prince Said Pasha, who turned out to be one of the ittikhadists a search was carried out by forces of 150 horse police officers and 200 infantry men. Allegedly, it is possible that there ittikhadists had the weapon". F. Karimi reports that despite prosecutions of Said pasha distribution of alms from his name still proceeds. "It is worth regretting while the Fatherland is on the brink of disaster really active people who are true defenders of the homeland are imprisoned or forced to run abroad. In such time all interparty conflicts had to be rejected aside, all sons of the fatherland, having rallied, had to protect the homeland. Here all are on the contrary..." (Karimi, 1913). F. Karimi visited the famous editor Ahmed-bei Agayev in prison of the military management. He provides his words: "We were brought here (into prison) by fidelity and love to the nation and the fatherland. Whether our diligence is right or wrong will be known later, the truth will become obvious" (Karimi, 1913). Criticizing the present Turkish authorities, nevertheless F. Karimi notes decent conditions of keeping of prisoners: good food, spacious rooms and even lack of lattices at windows.

Failures in new Balkan war struck on prestige of the government of Kyamil-pasha. After a truce the situation starts changing and F. Karimi writes about it in his notes: "As the question of the peace is being moved forward the case of party members of Ittikhad ve terakki is being softened as well". A few days ago with the words " innocent appeared to be taken into custody" several people were let out. Having taken the pledge, yesterday 18 more people were let out. Ahmed bei Agayev, the former Minister of Internal Affairs Haji Gadel bei, the former Minister of education Amrulla efenda, the former Minister of vaqufs affairs Hayri be and some people from the former deputies being among them. As for the others the inspection and investigation are allegedly carried out". F. Karimi notes that people didn't believe official statements, that Young Turks wanted to kill the padishah and the Minister of War (Karimi, 1913.). F. Karimi himself sympathizes with Young Turks: "People with the most advanced thoughts and defenders of Turkic peoples and Muslims are party members of "Ittikhad ve terakki", with the accusations of high treason, they are compelled to run abroad or imprisoned here" (Karimi, 1913).

At this time at the beginning of December, 1912 Galiaskar Kamal the correspondent of the Kazan newspaper "Yoldyz" arrived to Istanbul. In his messages to the newspaper "Yoldyz" G. Kamal gives much less a place to policy, to be exact to the interparty collisions, than F. Karimi. G. Kamal is interested in such subjects as economy, education, life, and so on ("Yoldyz", 1912).

By the end of 1912 the political situation in Istanbul was heated, the government lost already the remains of their authority but the influence of the Young Turks was growing. Return of Enver bei one of the leaders of "Ittikhad 
ve terakki" from Tripolitania which was captured by Italians became the important event which drew public attention and the press. F. Karimi and G. Kamal tried to meet and interview him. F. Karimi met Enver on December 14, 1912 and doesn't hide the admiration of this personality: "at the mention of the name of Enver bei who showed big heroism during the Turkish revolution and Tripolitan war on the faces of all Turks one can see pride and arrogance, everyone mentions his name with great respect and everyone wants to see and thank him". Further F. Karimi writes about the return of Enver bei from Tripolitania to Istanbul: "A big meeting wasn't arranged as for some reasons there wasn't full information about it, and he returned without any noise. On the other hand everyone felt the fall of the spirit because of the war disasters. The reason of everyone's mourning is the hard blow which was struck to the honor of the caliphate by the enemies. But even if the hearts of people are bleeding you can hardly see anyone crying. Everyone's heart is overflowed with the feeling of revenge. Knowing it, Enver bei himself wouldn't have accepted a grand reception" (Karimi, 1913.) On the meeting with Enver F. Karimi went together with the head of the "Turk yurdu" Yusuf bei Akchurov". From the first minute of personal acquaintance Enver made a very good impression on F. Karimi. Generally, F. Karimi describes that part of conversation which deals with Enver's stay in Tripolitania during the war with Italy. It should be mentioned that during the conversation there were two more officers in the room. Besides, Enver was visited by some people, he talked to some of them with journalists being present, and others were taken away to another room and asked to wait. And, at last, we find the ending of Karimi's record about Enver rather interesting: "Not to put such a great and dear person as Enver bei in an uncomfortable position, I didn't consider it necessary to ask him about some things and to write about some moments which he mentioned" (Karimi, 1913). There is still an open question, whether F. Karimi could know about Enver-bei's plans because in a few weeks Enver will head the plot which will lead to the government's overthrow and the Young Turks will return the power and rule the Ottoman Empire up to 1918. In fact, F. Karimi did not just attend the house of Enver-bei, but he visited one of the headquarters of conspirators.

\section{Discussion}

The subject of the Tatar journalists' activities in the Ottoman Empire during the Balkan wars was repeatedly raised in the works of Tatar researchers. In the introduction to the scientific and biographic collection devoted to Fatih Karimi, evaluating its "Istanbul letters", Academician M.A.Usmanov (Fatih Karimi, 2000) emphasized the fact that the Tatar journalist in 1913 saw the bankruptcy of imperial "Ottomanism" ideology (Fatih Karimi, 2000) Today, Alfina Sibgatullina (Sibgatullina, 2010) touches upon the topic of Tatar newsmen in Istanbul: "People like Fatih Karimi, were"theirs"for Turkey, who at the same time had a special" look" on the events that occurred in the Ottoman Empire. These were the people who knew the inside Turkey, but at that they were able to look at it from the side, i.e. more objectively with the broader view of the international situation of the country in the era of war and rebellion. This explains the originality of "letters" of F. Karimi"(Sibgatullina, 2010). But, despite the interest in the topic of the Tatar journalists in Turkey during the Balkan wars the question of lighting the political situation in the Ottoman Empire by the Tatar journalists and especially their personal involvement in the political struggle had almost no coverage in the historical literature.

\section{Conclusion}

During our research, we came to the following conclusions. In the autumn of 1912 the Ottoman Empire had one of the dramatic moments in its history. During the Balkan war almost all European areas were lost, and there was a real threat of capture of Istanbul by Bulgarian troops. The consequences of military defeat were redoubled by internal contradictions between parties and groups of the Ottoman ruling elite. The defeat of the Ottoman troops and the threat of the fall of the Ottoman Empire provoked a strong reaction among the Muslims of Russia (Volga-Ural Tatar). The Tatar newspapers and magazines tracked events in Turkey with the pain and anxiety. In this difficult time a few Tatar journalists came to Turkey to cover the war, but eventually they found themselves in the epicenter of political struggle in the capital of the Ottoman Empire. Reporters of the Tatar edition cover not only and not so much the course of military operations, and to a greater extent social and political life of the Ottoman Empire, and, apparently, some of the Tatar journalists become participants in the events.

The materials presented in the article highlight one of the faces of not fully investigated aspects of the Russian-Ottoman relations, namely the role of Russian Muslims in these relations. The article noted how seriously the fateful moments in the history of the Ottoman Empire formed by the part of the Muslims of Russia were taken, namely by the Volga-Urals Tatars. And here the Balkan wars period, in our opinion, is particularly important. Then, during the Balkan wars in the account of events in the Ottoman Empire Tatar editions enjoyed wide enough freedom from the imperial power, which is not the later events of the First World War. Being a long time in Turkey the Tatar journalists had close ties with local counterparts, as well as the current politicians. And here it is possible to formulate a problem that needs further study: to what extent the Tatar journalists were 
impartial observers and direct participants in the dramatic events of the last years of the Ottoman Empire.

\section{Acknowledgments}

The work is performed according to the Russian Government Program of Competitive Growth of Kazan Federal University.

\section{References}

Amirhanov, R. U. (2002). Tatapskaia dorevoliuzionnaia pressa v kontekste "Vostok-Zapad" (na primere razvitiia russkoi kultury). Kazan, 240.

Amirhanov, R. U. (2006). Tatarskii narod I Tatarstan v nachale XX vv.: istoricheskie zarisovki. Kazan': 152.

Fatih Karimi: Nauchno-biograficheskii sbornik. (2000). Kazan, 320.

Feroz, A. (2010). Ittihad ve terraki. İstanbul, 256.

Finkel, C. (2007). Osman's Dream: The Story of the Ottoman Empire 1300-1923. Basic Books, 674.

Genel Türk tarihi. (2002). Cilt 7. Osmanll. Ankara, 714.

Istoriia tatar s drevneishih vremion. (2013). V semi tomazh Tom VI. Formirovanie tatarskoi burzhuaznoi nazii. $X I X$ - nachalo $X X$ vv.centuries. Kazan, 1172.

Kərimi, F. (1913). Istanbul məktypləre (na staro-tatarskom iazyke, arabskaia grafika). Orenburg, 454.

"Koyash" (1912). (gazeta na staro-tatarskom iazyke, arabskaia grafika).

Osmanlı devleti ve medeniyeti tarihi. Cilt. 1. (1994). İstanbul: İslam Tarih, Sanat ve Kültür Araştırma Merkezi (IRCICA), 868.

Petrosyan, Y. A. (2003). Osmanskaia imperiia: mogushestvo i gibel: istoricheskie ocherki. Moskva, 380.

Sibgatullina, A. T. (2010). Kontakty tiurok-musulman Rossiiskoi I Osmanskoi imperii na rubezhe XIX-XX vekov. Moskva, 264.

V porokhovom pogrebe Evropy. 1878-1914. (2003). Moskva, 560.

"Vakyt." (1912). (gazeta na staro-tatarskom iazyke, arabskaia grafika).

Vasilieva, A. N., \& Gavrilov V. (2000). Balkanskiy tupik? (Istoricheskaia sud'ba of Yugoslavii v XX v.). Moskva, 480.

"Yoldyz." (1912). (gazeta na staro-tatarskom iazyke, arabskaia grafika).

Zadokhin, A. G., \& Nizovskiy, A. Y. (2000). Porokhovoi pogreb Evropy. Moskva, 416.

\section{Copyrights}

Copyright for this article is retained by the author(s), with first publication rights granted to the journal.

This is an open-access article distributed under the terms and conditions of the Creative Commons Attribution license (http://creativecommons.org/licenses/by/3.0/). 